\title{
Fostering Competencies in Future Teachers: A Competency-Based Approach to Teacher Education
}

\author{
Susan Cydis \\ School of Education, Richard Stockton College, Galloway, USA \\ Email: susan.cydis@stockton.edu
}

Received 28 May 2014; revised 30 June 2014; accepted 8 July 2014

Copyright (C) 2014 by author and Scientific Research Publishing Inc. This work is licensed under the Creative Commons Attribution International License (CC BY). http://creativecommons.org/licenses/by/4.0/

\begin{abstract}
The study investigated the characteristics of instruction and assessment used by instructors in teacher education courses that foster student competencies as perceived by students. The sampling method used to collect the sample of instructors and their courses was purposive, nonprobability sampling. Student participants included those that were currently registered in classes of the respective instructors. A qualitative analysis of the data collected revealed that instructors used a variety of competency-based educational practices in their instructional and assessment tasks and that students perceived themselves as competent in the areas identified by the Teacher Education Accreditation Council (2009) as standards for student competencies in teacher education courses.
\end{abstract}

\section{Keywords}

Authentic Instruction, Competencies, Outcome-Based Education, Performance Task Assessment, Student Learning Outcomes

\section{Introduction}

As student learning outcomes and competency-based models of instruction and assessment continue to be the focus of discussion in higher education, this study serves as an opportunity to contribute to a base of empirical data that supports the concept of student learning outcomes and competency-based models of instruction and assessment. This article presents the results of an analysis of the methods of assessment and instruction that foster student learning in teacher education courses as well as perceived levels of learning acquired by student participants. 
Cultivating a level of competency-based abilities that include strategic and reflective thinking may be one of the most critical aspects of the role of a teacher and one of the greatest strengths we can develop in our students. In recent years discussion in the field of higher education has included some very contentious debates focusing on learning and assessment. During this maelstrom of debate it seems important to pause and consider the purpose of higher education as a means for directing our efforts in a manner that is most productive from a broader perspective. In an editorial of a project entitled the National Forum of College-Level Learning, Miller (2008) refers to the concept of "educational capital" and poses the question, "What do the state's college-educated citizens collectively know and what can they do that furthers the social good?” Pragmatically colleges and universities are charged with the task of preparing students with the knowledge base and practical skills needed for success and productivity in the workplace (Lazerson, Wagener, \& Schumanis, 2000). In this age of information, we need to reform our model of education to better prepare students with the competencies they need for the global world of the twenty-first century (Jerald, 2009).

\section{Literature Review}

While efforts to reform teaching and learning practices in higher education have been a focus for many American college and university campuses at least as far back the 1980's (Lazerson, Wagener, \& Schumanis, 2000), reform efforts at the elementary and secondary level can easily be traced back as far as the Elementary and Secondary Education Act (ESEA) of 1965. This federal statute, The Elementary and Secondary Education Act was passed to fund primary and secondary education in the United States, emphasizing educational equality and establishing standards and accountability. The ESEA has been reauthorized many times, most notably in the form of the No Child Left Behind Act (2001) and most recently as A Blueprint for Reform (2010), making it the most far-reaching federal legislation affecting education ever passed. However, as a result of the focus on accountability and assessment, this created a culture of accountability systems that still exists today. With this increase in federal funding for public school education, there was a focus on monitoring student achievement to ensure effectiveness. While the federal government initiated the National Assessment of Educational Progress in 1969, to monitor student achievement in basic skills at the elementary and secondary level, there were low demands for assessment to demonstrate competency in students. Broad-based political support for testing as a measure of accountability has become the dominant mode of school reform in the United States (Feuerstein, 2011). This phenomenon partly served as a catalyst for the establishment of national standards and assessments proposed in the 1990s. Additionally, the release of the two federal reports, A Nation at Risk (National Commission on Education Excellence, 1983) and Becoming a Nation of Readers (Anderson, Hiebert, Scott, \& Wilkinson, 1985) cautions readers of the "rising tide of mediocrity" and low standards for performance in schools in the United States. This also served as cause for federal support for standards and assessment to increase competency and achievement in student performance.

These initiatives also had a strong impact on assessment and accountability at the post secondary level. US Secretary of Education Margaret Spellings' (2006) Commission on the Future of Higher Education centered on reform in higher education and federal accreditation as a means for monitoring, assessing and raising the standards for performance and quality of education in post secondary institutions, while Shavelson (2007) warned against narrow measures of student learning becoming a common presence in higher education. Despite their ease and inexpensive nature, Shavelson (2007) argues that these methods of assessment do not measure crucial skills such as reasoning involved in personal relations, moral challenges and civic engagement. Not including such measures could create a lack of value for their presence in the higher education curriculum (Shavelson, 2007).

Teacher education programs were not immune to these influences, and as a result of the concerns that arose, raising the quality of teacher education programs became a focus of reform. There is much research that supports the diminishing quality of teacher education programs that resulted from this phenomenon. Mehta (2008), Assistant Professor at the Harvard Graduate School of Education, argued that this new paradigm in education de-emphasized a more humanistic approach to instruction and instead placed an emphasis on goals of efficiency, which still prevails today and has a detrimental impact on educational reform. Consequently, Dorn (2007) argues that our current approach to education includes a rigid system of accountability, creating a focus on testing, which dehumanizes education and inhibits teachers from engaging students in authentic learning experiences that foster optimal learning. 
None-the-less, lesser-known efforts to raise the quality of education also existed despite the strong emphasis on assessment and accountability. As the Higher Education Reauthorization Act (1986) called for institutions of higher education to begin implementing accountability plans, researchers began to focus on how to increase the quality of student learning in the face of the era of reform that so strongly emphasized a culture of assessment. A study researching undergraduate education in higher education, (Wingspread Group in Higher Education, 1993) identified what they referred to as a dangerous mismatch between what undergraduates needed and what they were getting. It called for three fundamental issues: taking values seriously, putting student learning first, and creating a nation of learners (1993, p. 7). Groups such as the National Council for the Accreditation of Teacher Education (NCATE) developed standards for teacher education programs, and according to Fraser (2005) groups such as NCATE focused the direction of teacher education reform toward not only a standards-based approach, but also a competency-based approach, on what a prospective teacher demonstrates and is able to do in the classroom.

The Middle States Commission on Higher Education (MSCHE), an agency responsible for accrediting institutions, issued updated standards that included further concentration on assessment of student learning (2005). The commission outlined a four-step teaching-learning-assessment cycle that included 1) developing clearly articulated learning outcomes, 2) providing purposeful opportunities for students to achieve those learning outcomes, 3 ) assessing those learning outcomes and 4) using the results of those assessments to drive instruction and resource allocation (MSCHE, 2005).

During the same year the Council for Higher Education Accreditation (CHEA) called for members to apply for the CHEA Award for Institutional Progress in Student Learning Outcomes (Eaton, 2008). The criteria for this award considered by the CHEA to be the essential features of exemplary programs including exemplary practices in addressing student learning outcomes (Eaton, 2008). The CHEA emphasized the use of direct evidence of student achievement to judge performance. Judith Eaton, president of the CHEA, identified the characteristics of the instructional approach used by Indiana University-Perdue University Indianapolis, one of the CHEA Award recipients. This included:

"a high level of student performance in core communication and quantitative skills; critical thinking the integration and application of knowledge; intellectual depth, breadth and adaptiveness; understanding society and culture; and values and ethics” (Eaton, 2008: p. 23).

Her description of the characteristics at Mesa Community College, another of the CHEA Award recipients, included learning outcomes in nine areas:

"arts and humanities, cultural diversity, information literacy, numeracy, oral communication, problem solving/critical thinking, scientific inquiry, written communication, and workplace skills. A key feature of these outcomes is the extent to which they encompass both general intellectual and workplace skills” (Eaton, 2008: p. 24).

These efforts toward a competency-based approach were evidence of a change in the way we approach learning and assessment in the classroom, one that can be thought of as a "New Paradigm" (Barr \& Tagg, 1995). Barr and Tagg describe a model of education that is focused on the learner rather than the instructor. A more contemporary model of education engages students in an active role in the learning process that includes demonstrating the knowledge they are acquiring through meaningful tasks for learning and assessment. Additionally, Wolf (2012) confirms the importance of a learner-centered approach in her report for the Alliance for Excellent Education when she refers to what can be thought of as a need for a "culture shift" in education. She identified the needs of future teachers as those that will enable students to meet the demands of a global economy. Students must be able to think critically, communicate effectively, collaborate with others and analyze information effectively. A new culture in education requires relevant learning opportunities that engage students and foster independence and readiness for the workplace. Rather than a culture that focuses on assessment for accountability, we need to focus on fostering competent students by emphasizing a learner-centered environment.

The importance of this issue is recognized not only in the educational arena, but in the political arena as well. President Barrack Obama's Blueprint for Educational Reform (US Department of Education, 2010), identifies the need for a "world-class" model of education as a moral imperative for all students to ensure the American promise of equal opportunity. An important feature of this blueprint includes the importance of effective teacher preparation programs that promote competent teachers. This includes the need for competent teachers with the 
skills and abilities required to meet the demands of the classroom and successfully create a rigorous environment that fosters learning for all students.

Support for a competency-based approach to education is widely promoted by recognized authors and experts in world class models of education. Vivien Stewart, a well-known expert, author and speaker in international models of education argues that the quality of our schools rest upon the quality of its teachers. Stewart reports that $21^{\text {st }}$ century teachers need to possess $21^{\text {st }}$ century literacies in order to create the learning environments that will enable their students to develop such skills (Stewart, 2012). She identified the importance of a competency-based approach that focuses on the quality of educational outcomes as well as content and skills that adequately prepare students for a rapidly changing global environment as an essential component of developing a world class model of education. Stewart describes world-class models of education as those that hold teacher preparation programs accountable for initial teacher competencies.

Linda Darling-Hammond, Professor of Education at Stanford University and founder of the School Redesign Network in her research on school restructuring and teacher quality, identified the importance of preparing and developing teachers as an important feature of what are thought of as world-class models of education in countries such as Finland, Ontario, and Singapore (Darling-Hammond \& Rothman, 2011). She reports that important lessons can be learned from countries such as these, whose educational models result in part from their success with developing competent teachers. Additionally, she explains that efforts to improve teacher effectiveness lead to higher and more equitable student achievement. This is evidence once again of the need for developing competent teachers as an important focus of educational reform in the United States.

This focus on a new model of education is characterized by United States Secretary of Education, Duncan (2011) in the following manner,

"We need to radically change society's views of teaching from the factory model of yesterday to the professional model of tomorrow, where teachers are revered as the thinkers, leaders and nation-builders they truly are” (2012).

Reforming our teacher education programs requires a focus on a competency-based approach that integrates high standards for performance-based learning designed to foster competent teachers, prepared for the $21^{\text {st }}$ century.

Responding to the need to raise the bar in terms of quality teacher education programs, accreditation agencies such as TEAC and NCATE offer public assurance through the goals and standards they create and urge teacher education programs to adhere to. TEAC specifically identifies the importance of competent, caring and qualified professional educators. NCATE seeks to develop and maintain high standards to prepare teachers for practice. In 2010 when these agencies joined forces and became The Council for Accreditation of Educator Preparation (CAEP) 2010, they identified future goals and a mission that included not only raising the performance of practitioners in the nation's P-12 schools, but also raising standards for the evidence, which supports claims of quality. In so doing, CAEP leaders believe they will raise the stature of the entire profession.

\section{Statement of the Problem}

It seems clear from the discussion in the field of higher education that shifting our current model of education to one that includes high standards and a learner-centered, competency-based approach to education is an important focus for reform. Better models of teacher education will no doubt play an important part in educational reform and we need to consider the models that will focus on the learner, develop competencies and maintain high standards. Striking the right balance to reform in higher education requires an emphasis on maintaining high standards, yet at the same time ensuring high quality learning experiences that produce individuals with the skills and readiness needed for the workplace as well as the twenty-first century world. Voorhees (2001) proposes a model for setting institutional standards that includes making connections between student learning outcomes and accreditation. He reports that, "despite the advances and general interest in outcomes throughout higher education over the past decade, state indicator systems have only been able to approximate learning outcomes” (p. 6).

There is considerable evidence for the value of an approach that develops the skills and abilities needed for success in the real world and for that reason it is important for us to consider what a competency-based model might include. Voorhees (2001) proposes the measurement of learning outcomes in the form of student compe- 
tencies which is defined by the US Department of Education (2001) as the "combination of skills, abilities and knowledge needed to perform a specific task" (p. 1). These tasks require students to demonstrate the skills and abilities necessary to perform in the real world setting for which they would be applicable (Voorhees, 2001). A competency-based learning approach includes the use of student learning outcomes, objectives, skills and competencies (Voorhees, 2001). Mansilla (2005) proposes a "focus on broad cognitive abilities embedded in meaningful, holistic complex tasks and its focus on information technologies" as a method for learning assessment (p. 16). Defining student achievement and learning outcomes from a competency-based perspective as identified by Upcraft (1999) includes 1) complex cognitive skills, also known as critical thinking ability, 2) knowledge acquisition, known as subject matter mastery, 3) intrapersonal development such as values and self-esteem, 4) interpersonal skills to include appreciating human differences, 5) practical competence including career preparation skills, 6) civic responsibility to include a commitment to democratic ideas, 7) academic achievement and 8) persistence. Similarly, Alverno College, a well-known leader in the field of assessment in higher education, implements a competency-based approach to education that includes eight competencies students must acquire and demonstrate to graduate. These include 1) communication, 2) analysis, 3) problem solving, 4) valuing in decision-making, 5) social interaction, 6) global perspectives, 7) effective citizenship, and 8) aesthetic responsiveness. Careful consideration of these competency-based models of learning and assessment might lead to an analysis the aspects of student learning outcomes and the characteristics of assessment tasks that foster competency-based abilities in students.

\section{Methodology}

The purpose of this study was to identify the educational standards and features of a competency-based approach present in the educational practices of instructors as well as the learning outcomes that students believed they acquired at the end of the course. The educational standards were identified by the Teacher Education Accreditation Council (TEAC), which was the accrediting body at the time this study was conducted. (TEAC has since merged with the National Council for Accreditation of Teacher Education, to form the current accrediting body, the Council for Accreditation of Educator Preparation).

\subsection{Research Design}

The design of this research study is a mixed-method approach within the natural setting of a university's Teacher Preparation Program. It included a content analysis of instructor syllabi for the purpose of identifying the presence of educational practices designed to meet Quality Principle I: Evidence of student learning as defined by TEAC (2009). The perspectives of students were collected via a survey questionnaire at the conclusion of the each respective course. The level of acquired learning outcomes as identified by students resulting from course learning and assessment tasks was identified.

\subsection{Sampling}

The setting of this study occurred within a college level teacher education program on one of its three campuses. The sampling method used to collect the sample of instructors and their courses was purposive, non-probability sampling. The criteria for selecting courses for this study includes those that demonstrated the standards for teacher education as determined by Teacher Education Accreditation Council (2009) within the TEAC accredited teacher education program. The teacher preparation program in this study is TEAC accredited and includes three courses that demonstrate TEAC's criteria for evidence of student learning and two sections of each of these courses are offered for a total of six classes that were part of this study. Consequently instructors participating in the study included those six on staff in the teacher preparation program that were teaching one of the six aforementioned classes in the spring of 2010. The rationale for selecting these classes for the study was because they were those that included the integration of educational standards for accreditation by the Teacher Education Accreditation Council (2009). Student participants included those that were currently registered in classes of the respective instructors.

\subsection{Procedures}

After an initial content analysis of instructor syllabi for the purpose of identifying the presence of instructional practices designed to meet Quality Principle I: Evidence of student learning as defined by TEAC (2009), an in- 
terview of each instructor was conducted to further investigate the nature of the learning and assessment tasks utilized in each course.

The goal of the interview was to reveal the educational practices of instructors which were reflected on his or her respective syllabus. Instructors were asked a series of questions to ascertain the nature of the educational practices included in their respective courses and the extent to which they addressed the competency-based standards as identified by TEAC (2009). Instructors were asked to explain the task students were required to perform and the questions on the interview instrument were presented in order to identify features of a competency-based approach as revealed from the review of literature. These practices included features such as authenticity, constructivism, higher-order thinking skills, socio-cultural learning, skill integration and a civic-minded focus. The interviews assisted the researcher with gaining a deeper understanding of the competency-based features revealed from the review of literature and the TEAC standards that were present in the instructors' educational practices. A qualitative analysis of the data collected during the interviews assisted with investigating the phenomena surrounding instructors' educational practices and student perceptions with regard to their learning.

As part of the interviews and content analysis the researcher focused on the concept of constructivism. Within the concept of constructivism, students are required to partake in creating a product that demonstrates the knowledge they have acquired as a result of their investigative exploration of topics of interest to them (Dever \& Hobbs, 2000). Identifying the extent to which the educational practices build upon the concept of constructivism assisted the researcher in investigating the TEAC's (2009) standard 1.2, pedagogical knowledge, which requires program candidates to convert their knowledge of subject matter into compelling lessons. The researcher questioned instructors' extent to which the educational tasks were constructive in nature and integrated the use of strategies and skills required to assist students in fostering understanding.

The researcher then questioned instructors as to the extent that their educational tasks had meaning beyond the school setting and connected to the larger social context within which students live. The purpose of this question was to ascertain the presence of TEAC's standard 1.4.1 learning how to learn, which requires students to "demonstrate that they have learned how to learn information on their own, that they can transfer what they have learned to new situations, and that they have acquired the dispositions and skills of critical reflection that will support life-long learning in their field". This reflects Dewey's (1938) view of "educative experiences", those that include constructive tasks that afford learners the opportunity to apply their knowledge and skills in an authentic situation. In the review of literature this concept was connected to the concept of higher-order thinking skills which became the next focus of the instructor interview.

Instructors were questioned as to the extent that students were required to utilize higher order thinking skills to manipulate information via synthesis, application, analysis and evaluation. Kulieke et al. (1990) identify a new vision of learning as performance-based in which students are asked to perform, create, produce or do something that requires them to use higher-level, problem-solving skills imitating the manner of thinking required when completing real world tasks. This concept relates to the need for students to acquire the skills of critical reflection in TEAC's standard 1.4.1 learning how to learn in which students need to "demonstrate that they have learned how to learn information on their own, that they can transfer what they have learned to new situations, and that they have acquired the dispositions and skills of critical reflection that will support life-long learning in their field".

Socio-cultural learning became the next focus during the interviews and content analysis. Instructors were asked to identify the extent to which students in their classes were required to mediate the knowledge acquired with social interaction and the use of language (Vygotsky, 1978). This feature is identified by Newmann and Wehlage as substantive conversation and requires students to engage in verbal discourse surrounding the subject discipline as a means of fostering deeper understanding via shared perspectives (1993). TEAC's standard 1.4.2 multicultural perspectives and accuracy relates to this concept. According to TEAC, "Candidates must demonstrate that they have learned accurate and sound information on matters of race, gender, individual differences and ethnic and cultural perspectives". Newmann and Wehlage offer an example identified in the review of literature that involves more than just memorizing the concepts surrounding a political election, but instead understanding more complex aspects of election issues. Real-world connections refer to the extent to which the learning has meaning beyond the classroom, when the learning has a connection to the large social context within which students live (Newmann \& Wehlage, 1993). A school election provides a real-world connection and meaningful context for the learning to occur. Social support for learning is defined as an atmosphere that has high expectations for student learning, one that promotes risk taking in the learner (Newmann \& Wehlage, 1993). 
This can be exemplified through a political debate whereby students are encouraged to share and defend perspectives. Newmann and Wehlage (1993) emphasize the fact that each of these standards of authentic instruction plays a critical role in developing an appreciation for learning and ensuring the transfer of learning.

Skill integration was the next focus of the instructor interviews. Dewey (1915) identifies this concept as the integration of strategies to assist students with developing the ability to apply skills and strategies required to explore resources across the curriculum. Instructors were asked to consider the extent to which students are required to integrate the skills and knowledge they acquire. This concept of skill integration is reflected in TEAC's standard 1.4.3 technology which requires student to use appropriate technology in carrying out their professional responsibilities.

Finally the researcher sought to elicit from instructors an understanding of the extent to which their educational practices fostered a level of civic-mindedness in students. Newmann and Wehlage (1993) identified this as those tasks that had a connection to the large social context within which students live. This concept relates to TEAC's standard 1.3 caring and effective teaching skill, which requires students to be able to teach effectively in a caring way and to act as knowledgeable professionals.

Using the Future Teacher Competency Self-Assessment (Appendix) students were surveyed at the conclusion of each respective course to determine the levels of competency they believed they possessed as a result of their learning experiences in each course. The survey included statements based on the components of Quality Principle I: Evidence of student learning as defined by TEAC (2009). This includes component (1.1) of Quality Principle I, subject matter knowledge, which requires program to demonstrate student acquisition of understanding of subject matter knowledge deemed essential by the institution. Secondly, students must demonstrate, component (1.2) of Quality Principle I, the ability to convert their knowledge of subject matter into compelling lessons and thirdly, students are expected to act on their knowledge in a caring and professional manner, component (1.3) of Quality Principle I. Additionally, TEAC (2009) identifies what is referred to as cross-cutting themes as essential parts of each component of Quality Principle I. These include the integration of skills and content of a liberal arts education including: technology, learning to learn, and multicultural perspectives.

In response to each statement they were asked to rate their level of learning based on a Likert scale. The Likert scale included a four point scale, four indicating the strong agreement with the statement and one indicating strong disagreement with the statement. Means were calculated for each statement and the means of student responses for each of the twelve indicators ranked from highest to lowest relating to student perceived level of learning for each indicator. This analysis included comparing the themes that emerged relating to authentic, competency-based educational practices as a result of the content analysis of syllabi and instructor interviews to the scores on the Future Teacher Competency Self-Assessment (Appendix) for each of the courses in the study. Patterns were noted to determine which of the emerging themes fostered greater preparedness as perceived and identified by students using the Future Teacher Competency Self-Assessment (Appendix).

\section{Results}

The data collected in this study revealed that features of competency-based educational practices are present in each of the courses investigated in this study. The instructors teaching the courses in this university's teacher preparation program investigated in this study were found to be using five or six of the TEAC standards and features of competency-based educational practices described in the review of literature. While each class possessed at least five features of competency-based education, these features were not all the same for each class. Because instructors identified five and six features as those that they believed were accomplished by the educational tasks included in their respective classes, it was determined that each of the classes included a focused on fostering student competencies. This is illustrated in Table 1.

Three areas of competency-based features were found to be present in all six classes investigated as part of this study. As a result of the coded interview data, higher order thinking skills, socio-cultural learning and civicmindedness were identified in the coded interview data. Instructor interviews indicated that these three areas contributed to the competency-based educational practices used in the design and delivery of the learning and assessment tasks in their respective classes.

With regard to learning outcomes perceived by students, responses to student surveys indicated that as a result of the course work completed, students either agreed or strongly agreed that they possess each of the competencies identified on the Future Teacher Competency Self-Assessment student survey in Appendix. It is therefore determined that the practices used by instructors in each of these courses fostered competence in students as 
Table 1. Features of a competency-based approach per class.

\begin{tabular}{|c|c|}
\hline Class & Competency-Based Educational Practices Identified via Coding \\
\hline One & $\begin{array}{l}\text { - TEAC standard: Appropriately use technology as well as understand the need for technology to } \\
\text { carry out professional responsibilities } \\
\text { - Constructive in nature } \\
\text { - Higher order thinking skills } \\
\text { - } \quad \text { Cocio-cultural learning } \\
\text { Civic mindedness }\end{array}$ \\
\hline Two & $\begin{array}{l}\text { - } \quad \text { TEAC standard: Possessing caring and effective teaching skill } \\
\text { - } \quad \text { Higher order thinking skills } \\
\text { - Socio-cultural learning } \\
\text { - } \quad \text { Skill integration } \\
\text { - Civic-mindedness }\end{array}$ \\
\hline Three & $\begin{array}{l}\text { - TEAC standard: Evidence of student learning, subject matter and pedagogical knowledge } \\
\text { - } \text { Highenticity } \\
\text { - } \text { Socio-cultural learning } \\
\text { - Civic-mindedness }\end{array}$ \\
\hline Four & $\begin{array}{l}\text { - } \quad \text { TEAC standard: Possessing caring and effective teaching skill } \\
\text { - } \quad \text { Higher order thinking skills } \\
\text { - Socio-cultural learning } \\
\text { - } \quad \text { Skill integration } \\
\text { Civic-mindedness }\end{array}$ \\
\hline Five & $\begin{array}{l}\text { - TEAC standard: Evidence of student learning, subject matter and pedagogical knowledge } \\
\text { - } \text { Highenticity } \\
\text { - } \quad \text { Socio-cultural learning } \\
\text { - } \text { Civic-mindedness }\end{array}$ \\
\hline Six & $\begin{array}{l}\text { - TEAC standard: Appropriately use technology as well as understand the need for technology } \\
\text { to carry out professional responsibilities } \\
\text { - Constructive in nature } \\
\text { - Higher order thinking skills } \\
\text { - Socio-cultural learning } \\
\text { Civic mindedness }\end{array}$ \\
\hline
\end{tabular}

identified by their responses on the Future Teacher Competency Self-Assessment.

The mean of student responses for each indicator in each class was then calculated and the means were then ranked from highest to lowest for each class. The area of highest competency as perceived by students in each class was then determined by the researcher as that which had the highest mean in each class. The area of lowest competency as perceived by students in each class was determined by the researcher as that which had the lowest mean in each class. The competencies most frequently rated highest by students were found to be either in the area of metacognitive knowledge or caring and efficient teaching skill. The class mean for metacognitive knowledge held the highest ranking by students in four of the six classes and the class mean for caring and effective teaching skill was ranked either first or second by students in all six classes. The means collected from the survey data also revealed that students ranked subject matter knowledge last in all six classes in the study while the means for technology held either the second or third to last position in terms of students perceiving themselves competent in this area. This is illustrated in Table 2.

A final point that was identified as a result of the analysis of data relates to a variety of different features of competency-based educational practices used by instructors. Because instructors identified five and six features 
Table 2. Results of learning outcomes as perceived by students ranked from highest to lowest.

\begin{tabular}{|c|c|c|c|c|c|c|}
\hline \multirow{2}{*}{$\begin{array}{c}\text { Class } \\
\text { One }\end{array}$} & \multicolumn{2}{|c|}{ Highest Mean } & \multicolumn{2}{|l|}{ to } & \multicolumn{2}{|c|}{ Lowest Mean } \\
\hline & $\begin{array}{c}\text { Metacognitive } \\
\text { Abilities } \\
3.96\end{array}$ & $\begin{array}{r}\text { Pedagogical } \\
\text { Caring and Effec } \\
3\end{array}$ & $\begin{array}{l}\text { wledge \& } \\
\text { Teaching Skill }\end{array}$ & $\begin{array}{c}\text { Multicultural } \\
\text { Perspectives } \\
3.85\end{array}$ & $\begin{array}{c}\text { Technology } \\
\text { Knowledge } \\
3.62\end{array}$ & $\begin{array}{c}\text { Subject Matter } \\
\text { Knowledge } \\
3.58\end{array}$ \\
\hline Two & $\begin{array}{l}\text { Multicultural } \\
\text { Perspectives } \\
3.88\end{array}$ & $\begin{array}{c}\text { Caring \& Effective } \\
\text { Teaching Skill } \\
3.82\end{array}$ & $\begin{array}{c}\text { Metacognitive } \\
\text { Abilities } \\
3.80\end{array}$ & $\begin{array}{c}\text { Technology } \\
\text { Knowledge } \\
3.56\end{array}$ & $\begin{array}{c}\text { Pedagogical } \\
\text { Knowledge } \\
3.68\end{array}$ & $\begin{array}{c}\text { Subject Matter } \\
\text { Knowledge } \\
3.41\end{array}$ \\
\hline Three & $\begin{array}{r}\text { Multicult } \\
\text { Caring \& Eff }\end{array}$ & $\begin{array}{l}\text { Perspectives } \\
\text { ve Teaching Skill } \\
80\end{array}$ & $\begin{array}{l}\text { Pedagogical } \\
\text { Knowledge } \\
3.73\end{array}$ & $\begin{array}{c}\text { Technology } \\
\text { Knowledge } \\
3.65\end{array}$ & $\begin{array}{c}\text { Metacognitive } \\
\text { Abilities } \\
3.63\end{array}$ & $\begin{array}{c}\text { Subject Matter } \\
\text { Knowledge } \\
3.38\end{array}$ \\
\hline Four & $\begin{array}{c}\text { Metacognitive } \\
\text { Abilities } \\
3.92\end{array}$ & $\begin{array}{c}\text { Caring and Effective } \\
\text { Teaching Skill } \\
3.79\end{array}$ & $\begin{array}{c}\text { Multicultural } \\
\text { Perspectives } \\
3.75\end{array}$ & $\begin{array}{l}\text { Technology } \\
\text { Knowledge } \\
\quad 3.55\end{array}$ & $\begin{array}{c}\text { Pedagogical } \\
\text { Knowledge } \\
3.54\end{array}$ & $\begin{array}{c}\text { Subject Matter } \\
\text { Knowledge } \\
3.29\end{array}$ \\
\hline Five & Pedagog & $\begin{array}{l}\text { Knowledge Metacogn } \\
\text { g and Effective Teachi } \\
3.92\end{array}$ & $\begin{array}{l}\text { Abilities } \\
\text { kill }\end{array}$ & $\begin{array}{c}\text { Multicultural } \\
\text { Perspectives } \\
3.84\end{array}$ & $\begin{array}{c}\text { Technology } \\
\text { Knowledge } \\
3.75\end{array}$ & $\begin{array}{c}\text { Subject Matter } \\
\text { Knowledge } \\
3.71\end{array}$ \\
\hline Six & $\begin{array}{c}\text { Metacognitive } \\
\text { Abilities } \\
3.73\end{array}$ & $\begin{array}{c}\text { Caring and Effective } \\
\text { Teaching Skill } \\
3.64\end{array}$ & $\begin{array}{l}\text { Multicultural } \\
\text { Perspectives } \\
3.62\end{array}$ & $\begin{array}{c}\text { Technology } \\
\text { Knowledge } \\
3.45\end{array}$ & $\begin{array}{c}\text { Pedagogical } \\
\text { Knowledge } \\
3.36\end{array}$ & $\begin{array}{c}\text { Subject Matter } \\
\text { Knowledge } \\
3.14\end{array}$ \\
\hline
\end{tabular}

as those that they believed were accomplished by the educational tasks included in their respective classes, it was determined that each of the classes included a focus on fostering competencies in students. Each instructor used multiple competency-based educational practices and collectively instructors used a broader scope of competency-based educational practices. This data was revealed as part of the analysis of the content of instructor syllabi as well as during the instructor interviews.

\subsection{Discussion}

Voorhees (2001) presents a conceptual model which reflects a framework for performance-based learning and assessment designed to develop competency-based abilities in students. The traits and characteristics form the foundation for learning that students acquire upon which further learning is built. In this study, the skills, abilities and knowledge developed through the learning and assessment tasks in each course created a foundation upon which student competencies were fostered. Instructors used a competency-based approach built on TEAC standards. The educational practices used by instructors and the competencies fostered by those practices were identified by students as those they believed they possessed and ultimately prepared them for their professional community of teaching.

Voorhees (2001) emphasized the value of the learning and assessment tasks having a purpose in the context of the professional community for which the student is preparing. Competencies are then "the result of the integrative learning experiences in which skills, abilities and knowledge interact to form learning” (p. 9) intended to have meaning within the authentic context in which it is intended to be utilized. The learning tasks identified by the instructors in this study exemplify this type of task that Voorhees describes. The conclusion can therefore be drawn that the teacher preparation program investigated in this research study utilizes a competency-based approach and that this approach fosters perceived competencies in students.

Voorhees (2001) argues that there needs to be a focus on student learning outcomes and faculty need to know what they are trying to achieve in order to know if they have achieved it. The appropriate measures need to be utilized to achieve the learning. The instructors in this study clearly identified the features of a competencybased approach integrated in the learning and assessment tasks in the courses investigated and took appropriate measures to accomplish the learning. Through the implementation of the tasks students were able to successfully develop these competencies as identified by the data collected in the student surveys. Once again, because each 
of the courses was found to include many features of a competency-based approach to education, and because students either agreed or strongly agreed to perceived competence the researcher concluded that instructor practices included a competency-based approach and those practices fostered a perception of competency among students who enrolled in the instructors' classes. The courses in this investigation demonstrated Voorhees' model, which includes an emphasis on competencies being linked and embedded within courses across disciplines (Voorhees, 2001). This offers the opportunity for them to be reinforced in course syllabi and translated into individual course assignments.

Continuing to recognize instructional models in higher education and the potential they have for fostering student competencies will provide great support for the momentum of this movement. Hakel (1997) reports that a competency-based education approach requires an insightful educator with a commitment to ensuring the highest quality of education to students as well as an understanding that can only be fully comprehended by the experts in their respective disciplines (Mentkowski, 2000). To support this approach to competency-based learning and assessment faculty develop performance tasks that require students to demonstrate proficiency in their respective disciplines (Scherer, 1995). The model investigated as part of this study serves as an example of the role of insightful educators that support a competency-based model demonstrated by the learning and assessment tasks revealed as those that fostered student competencies in this investigation.

\subsection{Recommendations}

Further research and discussion surrounding competency-based educational practices has the potential to contribute to the current pool of research and data on this topic. Alverno College has developed what researchers refer to as a "Talent Driven Approach" designed to produce competent learners, skilled, strategic and ready for the workplace. The research of Mentkowski (2000) and her colleagues at Alverno College centers around an approach that integrates performance based learning at the post secondary level. As this model of learning and assessment continues to gain momentum more research needs to be conducted in support of this approach to learning and assessment in higher education. Doing so will assist researchers and practitioners with gaining better insight and pedagogy surrounding this valuable topic. As more models of competency-based approaches are identified they will serve as examples for other institutions. These models can then be utilized to assist other institutions with developing a model based on this competency-based approach to learning and assessment. A goal for this program and others will need to be devising meaningful learning and assessment tasks that require students to draw upon their subject matter knowledge and demonstrate the abilities they possess as a means of increasing their levels of competency in this area. Additionally, making technology a focus for integrating authentic tasks that rely on the use of technology will be an important consideration for this teacher education program as well as others as we prepare future teachers in the twenty-first century. Addressing these goals will enhance student understandings in these areas and support their ability to perceive themselves as more competent in these areas, an important consideration for a competency-based approach in higher education.

\subsection{Summary and Conclusions}

The research on the topic of assessment and reform in higher education seems to suggest that improving the quality of education in higher education can be accomplished by developing a competency-based educational model that includes performance-based education with authentic, integrated instruction measured by student learning outcomes.

Research proven best practices such as authentic instructional practices, integrated instruction and performance-based assessment have been the topic of conversation in educational journals and have been proven to enhance the quality education in adult learners (Purcell-Gates, Degener, Jacobson, \& Soler, 2002). This approach is exemplified in research proven models (Hakel, 2007) of competency-based approaches and they illustrate the manner in which educators need to acquire the strategies to successfully acquire and implement this approach to instruction and assessment. This research study offers the opportunity to consider the importance of a competency-based approach to education and serves a resource as teacher education instructors seek to implement more competency-based practices in the instructional practices.

\section{References}

Anderson, R. G., Heibert, E., Scott, J. A., \& Wilkinson, I. A. G. (1985). Becoming a Nation of Readers. Washington, D.C.: 
National Institute of Education. http://files.eric.ed.gov/fulltext/ED253865.pdf

Barr, R. B., \& Tagg, J. (1995). From Teaching to Learning: A New Paradigm for Undergraduate Education. Change, volume, 13-25.

Council for Accreditation of Educator Preparation (2010). Moving Educator Preparation to Excellence through Continuous Improvement and Research-Based Transformation. http://www.caepsite.org/

Darling-Hammond, L., \& Rothman, R. (Eds.) (2011) Teacher Leader Effectiveness in High Performing Education Systems. Washington, DC: Alliance for Excellent Education and Stanford, CA: Stanford Center for Opportunity Policy in Education. http://www.all4ed.org/files/TeacherLeaderEffectivenessReport.pdf

Dorn, S. (2007). Accountability Frankenstein. Charlotte, NC: Information Age Publishing.

Duncan, A. (2011). A New Approach to Teacher Education Reform and Improvement. Education Sector Forum. Washington, D.C.: Captital Hilton. http://www.ed.gov/news/speeches/new-approach-teacher-education-reform-and-improvement

Eaton, J. (2008). Attending to Student Learning, Change, 40, 22-29. http://dx.doi.org/10.3200/CHNG.40.4.22-29

Feuerstein, A. (2011) The Politics of Accountability and Teacher Preparation. Action in Teacher Education, 33, 3-23. http://dx.doi.org/10.1080/01626620.2011.559421

Fraser, J. W. (2005). Notes toward a New Progressive Politics of Teacher Education. Journal of Teacher Education, 56, 279284. http://dx.doi.org/10.1177/0022487105275841

Hakel, M. (1997). What We Must Learn from Alverno. About Campus, 2, 16-21.

Jerald, C. D. (2009) Defining a $21^{\text {st }}$ Century Education. Center for Public Education. http://www.centerforpubliceducation.org/Learn-About/21st-Century/Defining-a-21st-Century-Education-Full-Report-PDF .pdf

Lazerson, M., Wagener, U., \& Schumanis, N. (2000). Teaching and Learning in Higher Education, 1980-2000. Change, 32, 12-19. http://dx.doi.org/10.1080/00091380009601731

Mansilla, V. B. (2005) Assessing Student Work at Disciplinary Crossroads. Change, 37, 14-21. http://dx.doi.org/10.3200/CHNG.37.1.14-21

Mehta, J. (2008) How Did We Get Here? Paradigms, Fields and Professions in Education Policy. Politics of Education Association Bulletin, 33, 1-7. http://www.fsu.edu/ pea/newsletters/PEA_Bulletin_Fall_2008.pdf

Mentkowski, M. (2000). Learning That Lasts. San Francisco, CA: Jossey-Bass Inc.

Middle States Commission on Higher Education (MSCHE) (2005). Assessing Student Learning and Institutional Effectiveness. http://www.msche.org/publications/Assessment_Expectations051222081842.pdf

National Commission on Excellence in Education (1983). A Nation at Risk: An Imperative for Educational Reform. A Report to the Nation and the Secretary of Education United States Department of Education. http://www.ed.gov/pubs/NatAtRisk/risk.html

Scherer, M. (1995). How Alverno Shapes Teachers. Educational Leadership, 52, 50-54.

Shavelson, R. (2007). Assessing Student Learning Responsibly: From History to an Audacious Proposal. Change, 39 , 26-33. http://dx.doi.org/10.3200/CHNG.39.1.26-33

Spellings, M. (2006). A Test of Leadership: Charting the Future of U.S. Higher Education. http://www.ed.gov/about/bdscomm/list/hiedfuture/reports/pre-pub-report.pdf

Stewart, V. (2012). A World Class Education: Learning from International Models of Excellence and Innovation. Alexandria, VA: Association for Supervision and Curriculum Development.

Teacher Education Accreditation Council (2009). Quality Principles for Teacher Education Programs. http://www.teac.org/wp-content/uploads/2009/03/quality-principles-for-teacher-education-programs.pdf

Upcraft, M. L. (1999). Affordability: Responding to the Rising Cost of Higher Education. In C. S. Johnson, \& H. E. Cheatham (Eds.), Higher Education Trends for the Next Century: A Research Agenda for Student Success (pp. 13-18). Washington DC: American College Personnel Association.

US Department of Education (2001). No Child Left Behind Act. http://www.ed.gov/policy/elsec/leg/esea02/index.html

US Department of Education (2010). A Blueprint for Reform.

http://www2.ed.gov/policy/elsec/leg/blueprint/publication_pg5.html

Voorhees, R. A. (2001). Measuring What Matters: Competency-Based Learning Models in Higher Education. New Directions for Institutional Research, San Francisco, CA: Jossey-Bass Inc.

Wingspread Group in Higher Education (1993). An American Imperative: Higher Expectations for Higher Education. Racine, WI: Johnson Foundation. http://www.johnsonfdn.org/AmericanImperative/hiexp.html

Wolf, M. A. (2012). Culture Shift: Teaching in a Learner Centered Environment Powered by Digital Learning, Alliance for Excellent Education, Carnegie Corporation of New York. http://www.all4ed.org/files/CultureShift.pdf 


\section{Appendix. Future Teacher Competency Self-Assessment}

1) My ability to clearly communicate my knowledge about teaching is strong.

2) The knowledge I have about the learning process will support students’ ability to learn.

3) I have an understanding of how to improve my ability to be a successful teacher.

4) As a future teacher I value my ability to reach all pupils through their knowledge of individual and cultural differences.

5) I believe I have the ability to convert the knowledge I have acquired and create compelling lessons to meet the needs of my students.

6) Teacher collaboration will be an important resource for me in the field of teaching.

7) I believe I have the ability to foster relationships with students that will lead to achievement.

8) I believe my role as a teacher will be one that can have a larger impact on society.

9) I understand and have the ability to employ teaching technologies in my instructional practices.

10) World events past, present and future impact the field of teaching.

11) I think about how to improve my ability to be a successful teacher.

12) I possess the knowledge I need about how to teach.

$\begin{array}{lll}4 & 3 & 2\end{array}$

$\begin{array}{llll}4 & 3 & 2 & 1\end{array}$

$\begin{array}{lll}3 & 2 & 1 \\ 4 & 2 & 1\end{array}$

1

$\begin{array}{llll}4 & 3 & 2 & 1\end{array}$

$\begin{array}{lll}4 & 2 & 1 \\ 4 & & \end{array}$

$\begin{array}{llll}4 & 3 & 2 & 1\end{array}$

$\begin{array}{llll}4 & 3 & 2 & 1\end{array}$

$\begin{array}{llll}4 & 3 & 2 & 1\end{array}$

$\begin{array}{llll}4 & 3 & 2 & 1\end{array}$

$\begin{array}{llll}4 & 3 & 2 & 1\end{array}$

$\begin{array}{llll}4 & 3 & 2 & 1\end{array}$

$\begin{array}{llll}4 & 3 & 2 & 1\end{array}$

Please read each of the following statements and indicate the extent to which you agree with each statement using the following key: $4=$ agree strongly, 3 = agree, 2 = disagree, 1 = disagree strongly. 
Scientific Research Publishing (SCIRP) is one of the largest Open Access journal publishers. It is currently publishing more than 200 open access, online, peer-reviewed journals covering a wide range of academic disciplines. SCIRP serves the worldwide academic communities and contributes to the progress and application of science with its publication.

Other selected journals from SCIRP are listed as below. Submit your manuscript to us via either submit@scirp.org or Online Submission Portal.
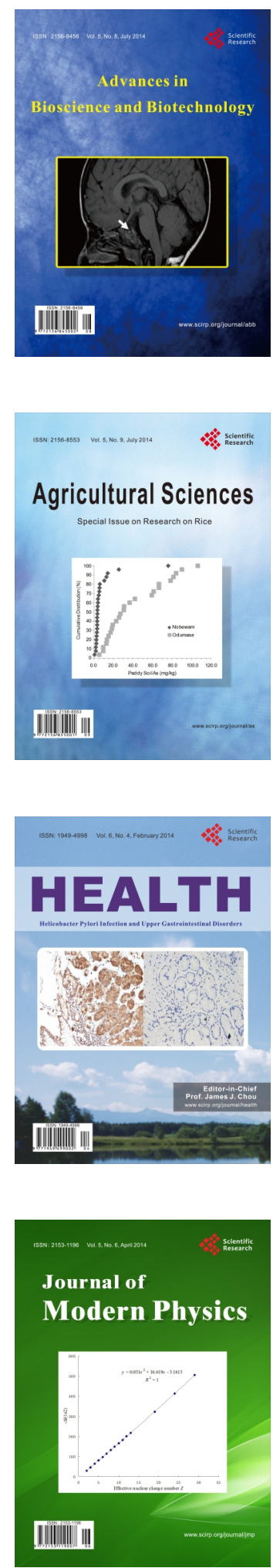
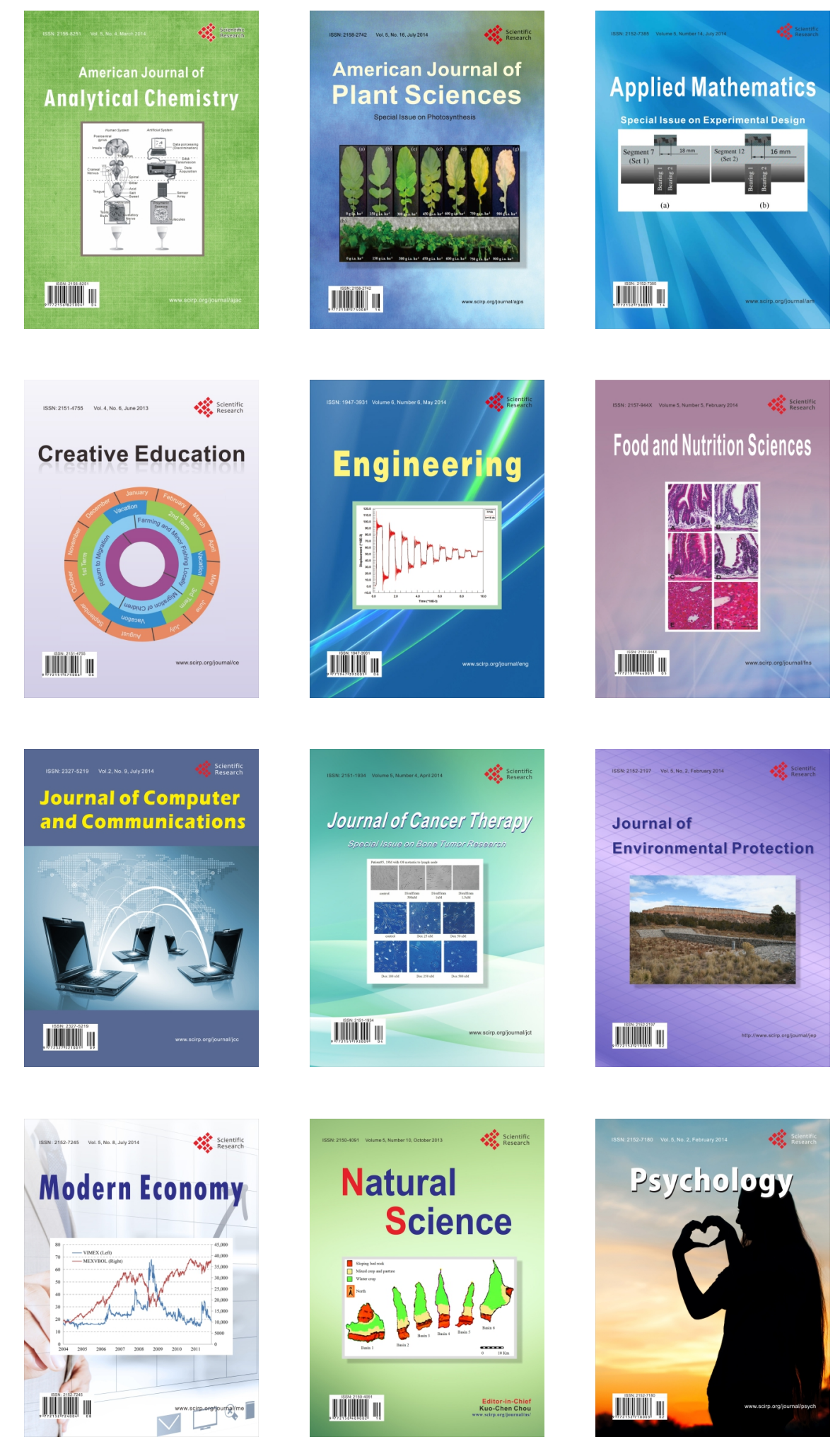